\title{
An exploratory study on low labour force participation of women in Sri Lanka
}

\author{
S. J. M. N. G. Samarakoon ${ }^{1^{*}}$ and Geetha Mayadunne ${ }^{2}$ \\ ${ }^{I}$ Department of Economics and Statistics, Faculty of Social Sciences and Languages, Sabaragamuwa University of Sri Lanka, Belihuloya, \\ Sri Lanka. \\ ${ }^{2}$ Socio-Economic Researcher
}

\begin{abstract}
Despite gender parity in education favoring female and positive outcomes in female education, about two thirds of the working age women in Sri Lanka do not participate in the labor force and stay at home. This study sought to understand the share distribution and incidence of stay at home women with different levels of education attainment and to identify reasons for non-participation. The analysis was based on quantitative data from the 2014 Labor Force Survey and 2012/13 Household Income and Expenditure Surveys of the Department of Census and Statistics, and on qualitative data collected from interviews with labor market experts. Quantitative analysis shows that the largest share and the highest incidence of working age women who do not participate in the labour force are upper secondary school dropouts. The lowest share and incidence are among those with tertiary education. Though the share of stay at home women with lower education was low, incidence was high. Irrespective of educational attainment, being married and having a household income were significant factors explaining non-participation in the labor force. Labour force participation of the tertiary educated women was not affected by maternal status, ethno religious identity or labor market factors. The qualitative data suggests the important role of reservation wages in the labor force participation decision of upper secondary school dropouts. The absence of soft and hard skills required to access jobs, meeting their reservation wage levels and the absence of employment guidance tend to impede their participation in the labor force.
\end{abstract}

Keywords: Women, labor force participation, reservation wage.

\section{INTRODUCTION}

In Sri Lanka, despite gender parity in education favoring female education, a large share of working age women does not participate in the labor force but stay at home. According to national labour statistics, on an average, annually, two thirds ${ }^{1}$ of the working age $^{2}$ women in Sri Lanka do not participate in the labor force ${ }^{3}$. Out of them, two thirds ${ }^{4}$ do not participate because they choose to stay at home, while a third pursue further education or training or they are unable to participate because they are old, disabled or sick. Given that female labor force participation is an important driver of economic development, especially from a household wellbeing perspective, why a large share of women stay at home without participating in the labor force is an issue requiring analysis.

As of 2014, globally, women ${ }^{5}$ are accounted for $31.8 \%$ of the global labor force (World Bank, 2015) and in South Asia, labor force participation rates vary across countries from 20\% in Pakistan, 38\% in Bangladesh, $27 \%$ in India to almost $80 \%$ in Nepal (Verick, 2014). In Sri Lanka, female labor force participation has remained stagnant at around 33\% since mid-ineties ${ }^{6}$. Global literature shows that on the demand side, female labor force participation is determined by the nature and level of growth and development of the country, with the

"Corresponding author (nimalakithsjm@gmail.com; (iD https://orcid.org/0000-0003-3690-7731)

This article is published under the Creative Commons CC-BY-ND License (http://creativecommons.org/licenses/ by-nd/4.0/). This license permits use, distribution and reproduction, commercial and non-commercial, provided that the original work is properly cited and is not changed anyway. 
supply and nature of jobs, wages, employer preferences, economic incentives such as taxation policies, labor laws, employee protection and support services playing significant roles, while in the supply side, woman's reproductive and child caring roles, marital status and maternal responsibilities, household income, education and cultural and social norms being major determinants.

In Sri Lanka, only a few studies have addressed the issue of low participation of women in the labor force, and these studies attempted to explain the reasons underlying women's participation or non-participation in the labor force. Gunathilake (2013), using 2008, 2009 Labor Force Survey (LFS) and 2009/10 Household Income and Expenditure (HIES, 2009/10) data ${ }^{7}$, and similarly, Chowdhury (2013), using HIES 2006/7 data, analyzed factors affecting non-participation. Gunathilaka (2013) focused on how it varied among three groups of women: married, single and female heads of households (irrespective of marital status) and found that age, education, ethno-religious identity, access to other incomes, domestic support, location and location specific labor market characteristics were important in explaining women's labour force participation rates. She discovered that the effects were markedly different across the three groups (Gunatilaka, 2013). She found that contrary to the pattern expected in the neo-classical labor supply model, wages did not play a role in the women's decision to participate or non-participate in the labour force. In his work, Chowdhury (2013) also claims, as Gunathilaka (2013), that similar characteristics are important in understanding the women's role in the world of work in relation to the labour force statistics. However, based on his findings, he points out the importance of the reservation wage in her decision to work or not to work for earning an income. Malhotra \& Degraff (2000) studied labor force participation of single and married women and the effect of social class and poverty on this decision. They noted that poverty promotes women's employment, regardless of marital status; however, young and married women of the upper-classes also seek employment to contribute to maintaining or improve the socio-economic status of the household.

Studies have not been carried out to explicitly understand the incidence of stay at home women across different levels of education attainment and reasons for their participation or non-participation in the labor force. To fill this information gap this study addresses three main research questions: (i) How does incidence of non-participation vary across the different levels of education attainment and by supply and demand factors; (ii) supply side and demand side factors explaining labor force non-participation of women with different levels of education attainment; (iii) why a large share of women with education up to upper secondary school level stay at home without participating in the labor force.

\section{THEORETICAL FRAMEWORK}

From a neo-classical economic perspective an individual's labor force participation and labor supply are explained by the theory of reservation wage and the labor-leisure choice model (e.g. Cahuc \& Zilberberg, 2004). An individual's decision to participate in the labor market depends on the gap between the individual's reservation wage rate and the market wage rate. The reservation wage rate is the minimum wage level at which an individual will accept to work. This definition of reservation wage implies that an individual will not work at all if the market wage is less than the reservation wage and the individual will enter the labor force only if the market wage exceeds the reservation wage. Therefore, whether or not an individual will enter the labor force will be based on a comparison of the individual's reservation wage and the market wage. This theory, therefore, implies that a high reservation wage makes it less likely that a person will participate in the labor force and vice versa. Therefore, a low reservation wage positively and a high reservation wage negatively affect the labor force participation decision. The labor-leisure choice theory postulates that wage rate and access to other (non-labor) income are the key economic variables influencing the supply of labor or the allocation of an individual's time between leisure and work. The theory implies that with reservation wage held constant, increases in market wage rate increase labor force participation. Because individuals prefer leisure to work, reservation wages rise as non-labor incomes increases. The reservation wage depends on many factors such as the individual's work preferences, the individual's education, individual's access to other incomes, and for women, possibly on the household responsibilities arising from marital and maternal status and cultural norms.

In the demand side, the availability of jobs in the labor market is the major factor affecting labor force participation. For women, gender segregation of jobs plays a negative role. As the economy evolves, the goods and services produced expands and the occupational segregation in the labor market increases, with some jobs being regarded as better suited for men (Reskin \& Cassirer, 1996; Huber, 1990). Gender segregation of jobs varies over time and across societies in response to changes in exogenous factors such as structural, technological and attitudinal changes. For example, Blumberger (1978) argued that the demand for female labor rather than the supply of women for work was the most important 
factor which raised female labor force participation in the western economies. In traditional agrarian societies high demand for female labor raised female employment but resulted in a decline in demand for female labor with advancement in agrarian technology (Cotter et al., 1998).

From a social perspective, functionalist theories (Macionis, 2010) suggest that gender inequalities exist as an efficient way to create division of labor where women are responsible for certain tasks such as reproduction and caring for the family, while men take up paid work to provide for the home. Women's responsibility for reproduction and time taken off for childbearing, child care and family maintenance lead them to make different decisions compared to men. These preferences by women affect their allocation of time to paid work versus unpaid domestic labor. However, feminist theories argue the importance of women's participation for overcoming household poverty and for positive outcomes for human capital and capabilities within the household and the society contributing to economic growth (Kabeer, 2013). Feminist theories argue that women are suppressed within the family structure, with women's choice of labor force participation additionally being affected by religious, cultural or social restrictions.

\section{METHODOLOGY}

To address the research questions, the study focusses on prime working age women, i. e. those women who are 25-54 years of age ${ }^{8}$, who stay at home without joining the labor force. In this study, these women are referred to as 'stay at home women' and defined as those women who are in their prime working age and who were neither sick, nor disabled, nor pursuing further academic or vocational education or training, but who opted to stay at home without participating in the labor force.

Both quantitative and qualitative research methods were used in the study. For the quantitative analysis, variables representing the supply side and demand side characteristics faced by the women were identified, based on the theoretical framework of labor force participation choice and the findings from related literature. Thus, the supply side variables selected are the level of education, marital status, maternal status, ethnicity of the woman and the woman's access to other incomes. Assuming that labor market characteristics, i. e. the availability of jobs and the market wage rates, are location specific, the province in which the woman lived and whether the location was urban, rural or estate were taken as proxy variables representing the demand side of the woman's labor force participation decision.

Logistic regressions were used to examine the binary choice of prime working age woman's participation in the labor force $(=0)$ or non-participation to stay at home $(=1)$. Logistic regressions were estimated for women with different educational attainment. Given that (Asian Development Bank, 2015) GCE O/L 9 and GCE $\mathrm{A} / \mathrm{L}^{10}$ examinations play a 'gate keeper' role in terms of accessing university or technical or vocational education $^{11}$, an individual passing or failing these examinations has a crucial bearing upon the individual's ability to gain employment and hence the educational attainment could have distinct relevance in explaining participation or non-participation in the labor force. The groups examined are: (1) Never schooled or only primary schooling; (2) Completed only lower secondary schooling (passed Grade 6-9); (3) Upper secondary but failed GCE O/L (passed Grade 10); (4) Passed GCE $\mathrm{O} / \mathrm{L}$ (Grade 11 or passed Grade 12); (5) Passed GCE A/L but could not access tertiary education; (6) Having tertiary education. Separate logistic regressions were carried out, placing women under six groups: (1) Never schooled or only primary schooling; (2) Completed only lower secondary schooling (passed Grade 6-9); (3) Upper secondary but failed GCE O/L (passed Grade 10) (4) Passed GCE O/L (Grade 11) or passed Grade 12; (5) Passed GCE A/L but could not access tertiary education; (6) With tertiary education.

The qualitative part of the study sought to triangulate the findings from the quantitative analysis and obtain information that did not emerge from the quantitative analysis.

The quantitative analysis was carried out using macro data collected by the Labor Force Survey (LFS) 2014 and the Household Income and Expenditure Survey (HIES) 2012/13 of the Department of Census and Statistics (DCS). Depending on the availability of required data, data from either the LFS 2014 or from HIES 2012/13 were used for the quantitative descriptive analysis. The logistic regression was based on HIES 2012/13 data. The qualitative data was collected through in-depth interviews with individual labor market experts.

\section{RESULTS AND DISCUSSION}

The distribution and the incidence ${ }^{12}$ of prime working age stay at home women by education attainment ${ }^{13}$ are shown in Figure 1 and Figure 2, respectively. These figures show that the percentage share of stay at home women and the incidence of stay at home women are the lowest for those with tertiary education. These are $1 \%$ and $7 \%$, respectively. The percentage share of stay at home women with either no schooling or only primary (Grade $1-5$ ) or lower secondary (Grade 6-9) schooling is about $30 \%$ and incidence is $49.8 \%$. The largest share $(69.2 \%)$ of stay at home women were those who had dropped out 


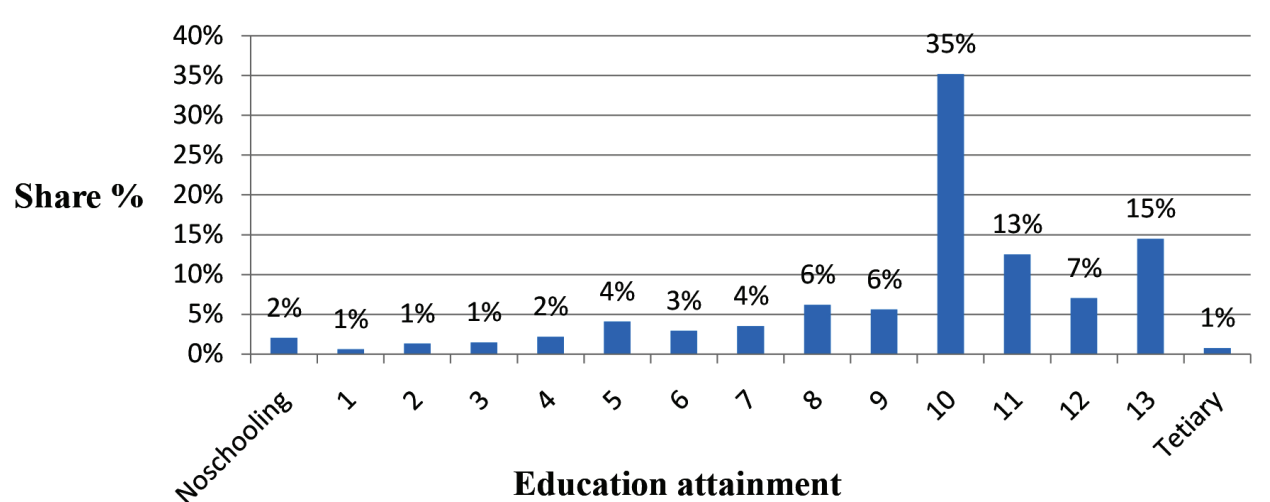

Figure 1: Distribution of stay at home women by education

Source: Authors' calculations based on (LFS, 2010-2014) data of the DCS

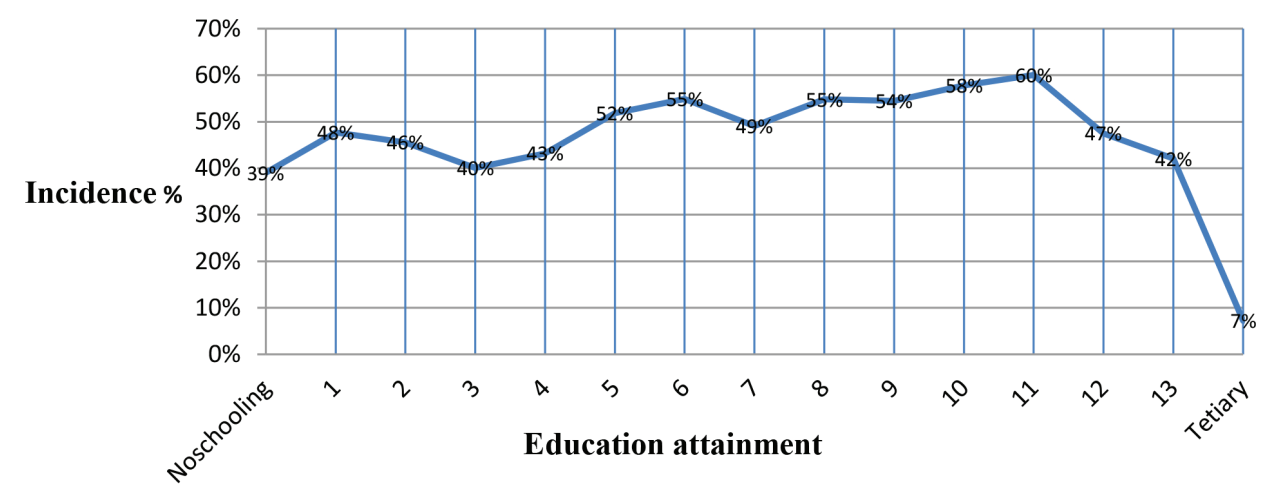

Figure 2: Incidence of stay at home women by education

Source: Calculations based on (LFS, 2010-2014) data of the DCS

Table 1: Incidence of stay at home women by education attainment and family status ${ }^{14}$

\begin{tabular}{|c|c|c|c|c|c|c|c|}
\hline & $\begin{array}{l}\text { Never schooled } \\
\text { or only primary }\end{array}$ & $\begin{array}{r}\text { Only lower } \\
\text { secondary }\end{array}$ & $\begin{array}{r}\mathrm{GCE} \mathrm{O} / \mathrm{L} \\
\text { Failed }\end{array}$ & $\begin{array}{r}\mathrm{GCE} \mathrm{O} / \mathrm{L} \\
\text { passed }\end{array}$ & $\begin{array}{r}\mathrm{GCE} A / \mathrm{L} \\
\text { passed }\end{array}$ & Tertiary & All \\
\hline Married ${ }^{15}$ with children & $64.1 \%$ & $69.2 \%$ & $77.3 \%$ & $80.5 \%$ & $70.8 \%$ & $16.2 \%$ & $72.0 \%$ \\
\hline $\begin{array}{l}\text { Married with no } \\
\text { children }\end{array}$ & $34.5 \%$ & $40.4 \%$ & $32.6 \%$ & $31.6 \%$ & $22.1 \%$ & $3.2 \%$ & $30.2 \%$ \\
\hline Single with children & $41.2 \%$ & $40.4 \%$ & $38.4 \%$ & $51.5 \%$ & $33.1 \%$ & $13.8 \%$ & $40.1 \%$ \\
\hline Single with no children & $19.0 \%$ & $22.1 \%$ & $24.8 \%$ & $17.8 \%$ & $10.7 \%$ & $3.3 \%$ & $16.6 \%$ \\
\hline
\end{tabular}

Source: Authors' computations using (HIES, 2012/13) (DCS) macro data. 
of school at the upper secondary level, and the incidence of stay at home women is the highest $(52.9 \%)$ among the upper secondary dropouts. Women who dropped out before sitting GCE O/L examination, those who failed GCE O/L examination, those who dropped out before GCE A/L or failed GCE A/L and those who passed GCE $\mathrm{A} / \mathrm{L}$ but did not continuing to tertiary, fall into this group.

\section{Marital \& family status}

Table 1 gives the incidence of stay at home women by the education levels and by marital and family status. It shows that for all levels of education, incidence of stay at home women are highest among those women who are married with children ${ }^{16}$. Incidence rates dramatically fall for those who are married but who have no children. Similarly, incidence is high for single women with children and again falls for single women without children. Comparing incidence levels between married women and single women, the reserchers observed that for all education groups, incidence is high for married women. The indication is that having children and being married are likely to interfere with labor force participation decisions. For the different marital and family status across the education levels, a systematic pattern in the incidence is not shown except that incidence is the lowest for those with a tertiary education.

\section{Access to other incomes}

Labor force participation choice of a woman could depend on other incomes accessible to the woman. A household could receive income from different sources, but it is not possible to assume that the women had access to all those incomes. In the absence of information on accessible other incomes, location in the household income distribution was taken as an approximate indicator to woman's access to other incomes. The share of stay at home women across household income quintiles are shown in Figure 3 and the incidence of stay at home women across household income quintiles and education levels are shown in Table 2. Across income quintiles the share of stay at home women in the poorest income quintile is low, but the incidence of stay at home women turn out to be highest in the poorest quintile.

The low share is due to the absolute number of prime working age women in the poorest quintile being relatively low compared to the prime working age women in the other quintiles. A large share of men and women in the poorest income quintile are old aged and beyond the prime working age. Therefore, both the share of prime working age women and, relative to the stay at home population in other quintiles, the share of stay at home women are lowest in the poorest income quintile. However, relative to the size of the prime working age women population in the poorest quintile, incidence of stay at home women are high, indicating that many women in the lowest income decile are not in the labor force. Low education among the poor, lack of skills in accessing job markets, lack of job market information and social networks might be preventing women from entering the labor market. In addition, individuals in the poorest income quintile are in precarious employment

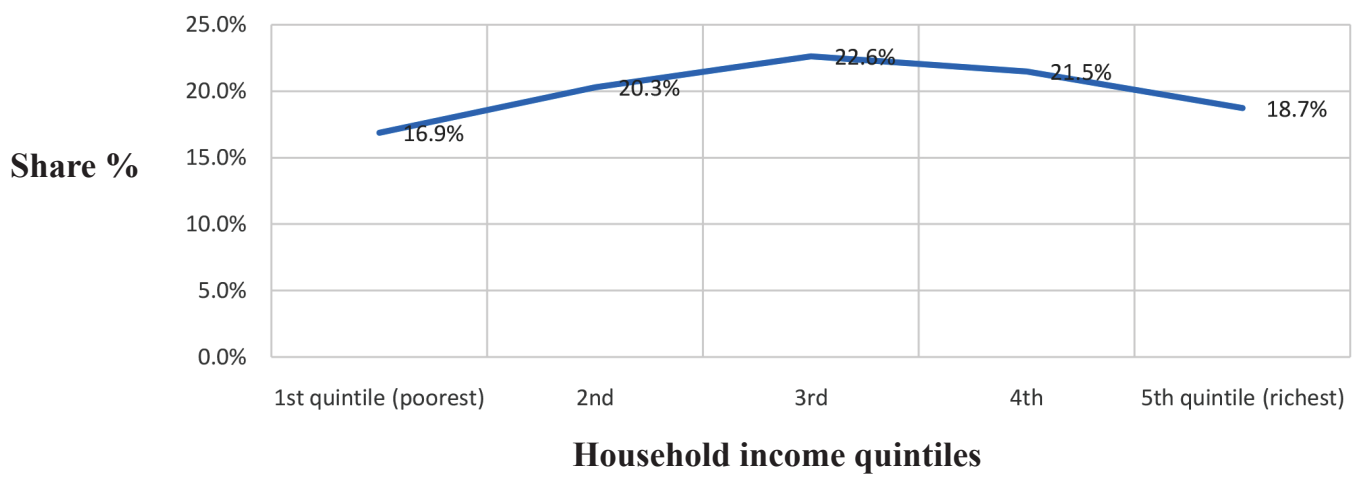

Figure 3: Percentage shares of stay at home women by income quintiles Source: Authors' computations using (HIES, 2012/13) (DCS) macro data 
Table 2: Incidence of stay at home women by education and income quintiles

\begin{tabular}{|c|c|c|c|c|c|c|c|}
\hline Income Quintile & $\begin{array}{l}\text { Never schooled } \\
\text { or only Primary }\end{array}$ & $\begin{array}{r}\text { Only Lower } \\
\text { Secondary }\end{array}$ & $\begin{array}{r}\mathrm{GCE} \mathrm{O} / \mathrm{L} \\
\text { Failed }\end{array}$ & $\begin{array}{r}\mathrm{GCE} \mathrm{O} / \mathrm{L} \\
\text { Passed }\end{array}$ & $\begin{array}{r}\text { GCE A/L } \\
\text { Passed }\end{array}$ & Tertiary & All \\
\hline $1^{\text {st }}$ quintile (poorest) & $59.3 \%$ & $68.0 \%$ & $68.7 \%$ & $71.7 \%$ & $76.0 \%$ & $23.1 \%$ & $67.0 \%$ \\
\hline $2^{\text {nd }}$ & $52.8 \%$ & $69.1 \%$ & $71.0 \%$ & $72.9 \%$ & $65.1 \%$ & $16.1 \%$ & $65.5 \%$ \\
\hline $3^{\text {rd }}$ & $50.3 \%$ & $68.6 \%$ & $72.7 \%$ & $71.0 \%$ & $58.9 \%$ & $26.8 \%$ & $64.8 \%$ \\
\hline $4^{\text {th }}$ & $48.3 \%$ & $62.2 \%$ & $63.5 \%$ & $61.3 \%$ & $51.3 \%$ & $7.0 \%$ & $56.4 \%$ \\
\hline $5^{\text {th }}$ quintile (richest) & $50.7 \%$ & $64.0 \%$ & $63.3 \%$ & $55.9 \%$ & $38.2 \%$ & $5.4 \%$ & $46.0 \%$ \\
\hline
\end{tabular}

Source: Authors' computations using (HIES, 2012/13) (DCS) micro data

which are physically strenuous and despite the need to survive only a low share of women opt to enter the precarious labor market. Further, in the poorest quintile, the highest incidence is among those who have passed GCE $\mathrm{O} / \mathrm{L}$ or GCE A/L. This could be a reflection of their financial incapability of accessing skills required for employment or their social background acting as a restricting factor to access formal employment in par with their education.

Across income quintiles, incidence falls with increasing income but shows an erratic pattern across education levels. However, both the share and the incidence of stay at home women are low in the highest income quintile. Women in higher income quintiles have better access to education and skills training; they are likely to have better access to employment information, placing them in the best position to be employed or seek employment, and hence among the rich the lowest incidence is among the better educated because they are likely to have qualifications, skills and social contacts to access employment.

\section{Ethnicity}

Table 3 shows that the ratio of stay at home women population to working age women population is the largest for Muslims (75.6\%) while it is $46.9 \%$ and $49.1 \%$ for Sinhala and Tamil women. Among Muslim communities, although the attitude towards women joining the labor force has changed over time with more Muslim women seeking employment, the data shows that labor force participation is low, compared to other ethnic groups. Across education groups, even among the tertiary educated, $17 \%$ of the women stay at home. Sinhala and Tamil women follow a similar pattern. However, more Tamil women with higher education have joined the labor force compared to the Sinhala women.

\section{Sectoral and provincial location}

The largest incidence $(55.5 \%)$ of stay at home women are in the urban sector, $49.5 \%$ are in the rural sector and the lowest incidence $(20.4 \%)$ is in the estate sector (Table 4). Compared to urban and rural sectors, in the estate sector, there is greater opportunity for women to be employed, and it is especially so in the tea plantations. Tea plantations dominate the entire estate sector in terms of extent and volume of the work force. Plucking tea leaves is an exclusively female job and almost all of the working age estate sector women are engaged in tea plucking. In tea plantations, over $99 \%$ of the tea pluckers are women and $56 \%$ of the worker force are women. In rubber plantations, over $49 \%$ of the work force are

Table 3: Incidence of stay at home women by education and ethnicity

\begin{tabular}{lrrrrrrr}
\hline Ethnicity & $\begin{array}{r}\text { Never schooled } \\
\text { or only Primary }\end{array}$ & $\begin{array}{r}\text { Only Lower } \\
\text { Secondary }\end{array}$ & $\begin{array}{r}\text { GCE O/L } \\
\text { Failed }\end{array}$ & $\begin{array}{r}\text { GCE O/L } \\
\text { Passed }\end{array}$ & $\begin{array}{r}\text { GCE A/L } \\
\text { Passed }\end{array}$ & Tertiary & All \\
\hline Sinhala & $37.8 \%$ & $47.9 \%$ & $55.5 \%$ & $53.5 \%$ & $41.5 \%$ & $7.3 \%$ & $46.9 \%$ \\
Tamil & $39.8 \%$ & $54.6 \%$ & $64.1 \%$ & $56.2 \%$ & $35.5 \%$ & $3.0 \%$ & $49.1 \%$ \\
Moor (Muslim) & $81.8 \%$ & $79.0 \%$ & $77.9 \%$ & $72.9 \%$ & $64.3 \%$ & $17.0 \%$ & $75.6 \%$ \\
Other & $78.9 \%$ & $78.6 \%$ & $61.5 \%$ & $54.2 \%$ & $20.9 \%$ & $84.5 \%$ & $57.4 \%$ \\
\hline
\end{tabular}

Source: Authors' computations using HIES 2012/13 (DCS) micro data. 
Table 4: Incidence of stay at home women by education and sector

\begin{tabular}{|c|c|c|c|c|c|c|c|}
\hline Sector & $\begin{array}{l}\text { Never schooled } \\
\text { or only primary }\end{array}$ & $\begin{array}{r}\text { Only Lower } \\
\text { secondary }\end{array}$ & $\begin{array}{r}\text { GCE O/L } \\
\text { Failed }\end{array}$ & $\begin{array}{r}\mathrm{GCE} \mathrm{O} / \mathrm{L} \\
\text { passed }\end{array}$ & $\begin{array}{r}\mathrm{GCE} A / \mathrm{L} \\
\text { passed }\end{array}$ & Tertiary & All \\
\hline Urban & $60.6 \%$ & $64.5 \%$ & $65.7 \%$ & $62.5 \%$ & $47.4 \%$ & $8.6 \%$ & $55.5 \%$ \\
\hline Rural & $46.6 \%$ & $53.6 \%$ & $57.0 \%$ & $53.2 \%$ & $40.9 \%$ & $7.1 \%$ & $49.5 \%$ \\
\hline Estate & $16.0 \%$ & $17.2 \%$ & $34.4 \%$ & $41.8 \%$ & $5.7 \%$ & $0.0 \%$ & $20.4 \%$ \\
\hline
\end{tabular}

Source: Authors' computations using HIES 2012/13 (DCS) micro data

women (Kotikula \& Sorotaroff, 2006). Further, many of the plantations have child care facilities which allows women to work while the children are taken care of by the crèche facilities. Women with infants are allowed a specific number of hours to breast feed infants, and work hours and payment rates are such that women have an equal opportunity to earn as much as men do. Availability of jobs, supported with these incentives, are likely to be the main driving factor of higher female employment in the estate sector. Annual Labor Force Survey data shows that female labor force participation rate of estate women is much higher than female labor force participation rates in Sri Lanka. According to Sri Lanka Labor Force Survey 2014 (LFS, 2010-2014), estate sector female labor force participation rate is 55.8 percent, 19 percentage points higher than that of rural sector and 12 percentage points higher than that of the urban sector. Availability of jobs and incentives are likely to be important demand side factors, driving women to participate in the labor force. However, a large incidence of stay at home women in the rural sector is puzzling. The technological developments in the rural agriculture sector displacing women from traditional agricultural work, and a lean job market due less economic activity in the rural sector could be possible reasons. Given ideas about dignity of labour, the parents in farming families may actively discourage their sons and daughters with educational qualifications to take up farming as an occupation.

The provincial distribution and incidence of women who stay at home are shown in Figure 4 and Table 5. Across Provinces, the lowest incidence of stay at home women are in the Provinces with large estate sectors; e.g. Uva Province (34.7\%) and Central Province(43.0\%), and in Provinces where Agriculture GDP is high; e.g. North Central Province $42.8 \%$ and North Western Province $45.2 \%$. The high share of stay at home women in the Eastern Province (68.2\%) is likely to be due to the large Muslim population in the Eastern Province. Western Province contributes the largest share of the GDP but $54.9 \%$ of the prime working age women stay at home.
Figure 4 shows that it has the largest stay at home women population (30\%). It could be that high level of economic activity in the urban sector in the Western Province and urban-rural connectivity within the Province, allow other family members, especially their spouses, to be employed, enabling these women to have access to "other" incomes- incomes of their spouses or immediate family members, thus discouraging women to work.

The researchers examined provincial and sectoral level wages and availability of jobs to further understand labor force participation across Provinces. High unemployment in their locations as well as low wages which might be below their reservation wages possibly discourage women in entering the labor market. Table 6 gives the unemployment rates and the median monthly wage rate for women across their residential locations.

The researchers find that among the upper secondary educated, unemployment rates as well as wage rates are high, compared to lower secondary educated women. Upper secondary dropouts due to their better education, might be having higher reservation wages, preventing accepting jobs with wages not different from those received by the lower educated. Therefore, high unemployment and low wage rates that are not matching their reservation wages could be the factor discouraging upper secondary dropouts participation in the labor force. For tertiary educated, though in some districts unemployment rates are high, higher wage rates make leisure too costly, driving them to seek employment.

\section{Statistical significance of identified factors on labor force participation choice}

The researchers examined the statistical significance of variables, representing the supply and demand side factors, on the binary choice of opting out of the labor force to stay at home $(=1)$ or joining the labor force $(=0)$, using Logistic regression models estimated for the six educational groups. Table 7 and Table 8 give the logistic regression results. 


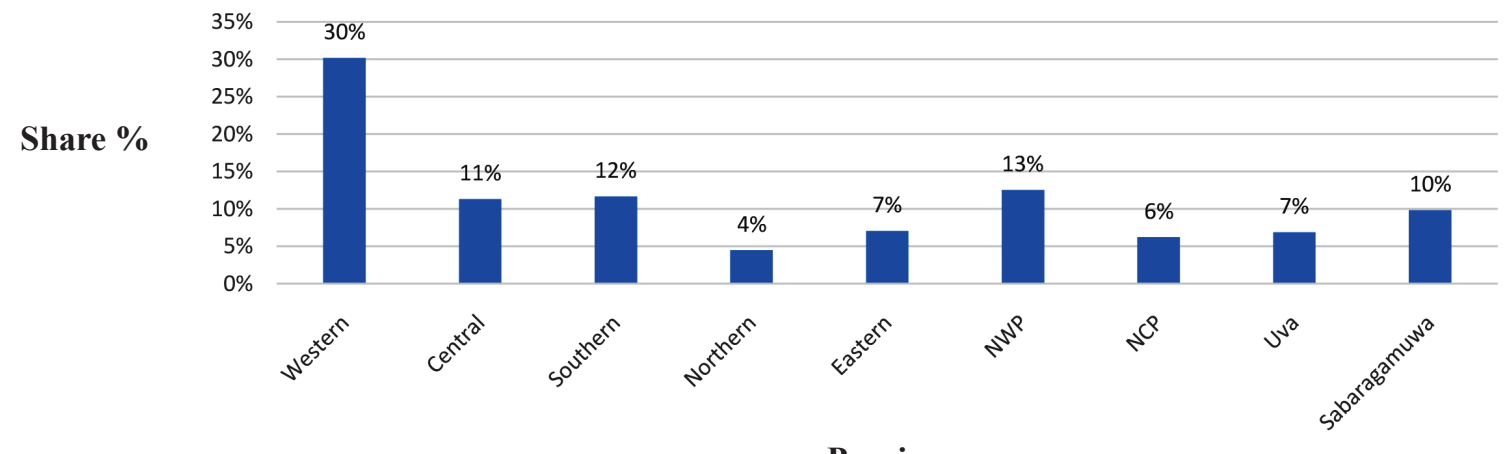

Provinces

Figure 4: Percentage share of stay at home women by Province

Source: Authors' computations using HIES 2012/13 (DCS) micro data

Table 5: Incidence of stay at home women by education and Province

\begin{tabular}{|c|c|c|c|c|c|c|c|}
\hline Province & $\begin{array}{l}\text { Never schooled } \\
\text { or only primary }\end{array}$ & $\begin{array}{r}\text { Only Lower } \\
\text { secondary }\end{array}$ & $\begin{array}{r}\text { GCE O/L } \\
\text { Failed }\end{array}$ & $\begin{array}{r}\mathrm{GCE} \mathrm{O} / \mathrm{L} \\
\text { passed }\end{array}$ & $\begin{array}{r}\text { GCE A/L } \\
\text { passed }\end{array}$ & Tertiary & All \\
\hline Western & $52.4 \%$ & $58.4 \%$ & $64.4 \%$ & $62.0 \%$ & $49.1 \%$ & $10.1 \%$ & $54.9 \%$ \\
\hline Central & $32.0 \%$ & $42.6 \%$ & $54.6 \%$ & $49.4 \%$ & $37.5 \%$ & $6.1 \%$ & $43.0 \%$ \\
\hline Southern & $38.1 \%$ & $46.9 \%$ & $58.7 \%$ & $50.0 \%$ & $35.0 \%$ & $4.3 \%$ & $46.4 \%$ \\
\hline Northern & $59.7 \%$ & $67.3 \%$ & $67.3 \%$ & $57.4 \%$ & $40.5 \%$ & $0.0 \%$ & $58.0 \%$ \\
\hline Eastern & $71.1 \%$ & $80.2 \%$ & $73.6 \%$ & $66.9 \%$ & $42.8 \%$ & $3.2 \%$ & $68.2 \%$ \\
\hline Northwestern & $42.3 \%$ & $54.0 \%$ & $51.0 \%$ & $50.8 \%$ & $33.2 \%$ & $8.6 \%$ & $45.2 \%$ \\
\hline Northcentral & $37.0 \%$ & $44.8 \%$ & $51.2 \%$ & $39.8 \%$ & $36.5 \%$ & $4.0 \%$ & $42.8 \%$ \\
\hline Uva & $29.5 \%$ & $26.8 \%$ & $41.7 \%$ & $44.8 \%$ & $33.0 \%$ & $7.3 \%$ & $34.7 \%$ \\
\hline Sabaragamuwa & $37.3 \%$ & $51.1 \%$ & $54.7 \%$ & $51.8 \%$ & $45.4 \%$ & $7.0 \%$ & $47.8 \%$ \\
\hline
\end{tabular}

Source: Authors' computations using HIES 2012/13 (DCS) micro data

For all education levels, a woman's marital status was found to be statistically significant at a $99 \%$ level of confidence, suggesting that marital status is a key factor affecting the labor force participation of a women, irrespective of the woman's education level. For all except the tertiary educated, having children below 10 years turned out to be a significant factor affecting the labor force participation. For those who were tertiary educated, either their incomes enabled them to afford child care or their high opportunity cost of staying out of the labor force made them join the labor force, possibly making alternative arrangements for the child. For all except the tertiary educated, ethnicity turned out to be a significant factor affecting the labor force participation, possibly due to the presence of the Muslim ethnoreligious group. However, for the tertiary educated, ethnicity was insignificant, indicating that if the women were better educated, they were likely to ignore ethno-religious cultural taboos where they exist. For all except the tertiary educated, the Province and the sector (whether urban or rural or estate) turned out to be significant factors affecting their labor force participation, the indication being that for all women, except those with a tertiary education, the Province and the sector related labor market factors are likely to affect the labor force participation decision. For women in all education levels, the household income level turned out be a significant factor affecting their labor force participation. Further, a highly constant coefficient indicates the existence of factors other than those considered in the regression, which might affect the labor force participation choice. 
Table 6: Unemployment rates \& wage rates in the geographic locations

\begin{tabular}{|c|c|c|c|c|c|c|}
\hline \multirow[t]{2}{*}{ Province } & \multicolumn{4}{|c|}{ Female unemployment rates } & \multicolumn{2}{|c|}{ Monthly wages/salaries (Median) } \\
\hline & Urban & Rural & Estate & Urban & Rural & Estate \\
\hline \multicolumn{7}{|c|}{ For women with primary or lower secondary education } \\
\hline Western & $2.4 \%$ & $2.8 \%$ & $2.0 \%$ & 10,276 & 10,099 & 9,505 \\
\hline Central & $0.0 \%$ & $0.0 \%$ & $0.0 \%$ & 7,128 & 7,089 & 7,540 \\
\hline Southern & $0.0 \%$ & $0.0 \%$ & $0.0 \%$ & 6,352 & 6,539 & 6,596 \\
\hline North & $3.5 \%$ & $3.6 \%$ & * & 6,644 & 6,629 & * \\
\hline East & $9.6 \%$ & $9.5 \%$ & * & 6,726 & 6,876 & * \\
\hline Northwest & $2.8 \%$ & $3.7 \%$ & $2.0 \%$ & 5,975 & 5,900 & 5,861 \\
\hline Northcentral & $4.7 \%$ & $1.7 \%$ & $1.4 \%$ & 2,324 & 2,042 & 2,385 \\
\hline Uva & $0.0 \%$ & $0.0 \%$ & $0.0 \%$ & 5,321 & 5,240 & 5,655 \\
\hline Sabaragamuwa & $0.0 \%$ & $0.0 \%$ & $0.0 \%$ & 7,745 & 7,720 & 7,850 \\
\hline \multicolumn{7}{|c|}{ For women with upper secondary education } \\
\hline Western & $4.5 \%$ & $4.1 \%$ & $3.2 \%$ & 15,608 & 15,260 & 14,629 \\
\hline Central & $14.1 \%$ & $12.4 \%$ & $11.1 \%$ & 11,295 & 9,934 & 8,595 \\
\hline Southern & $14.3 \%$ & $13.5 \%$ & $14.0 \%$ & 11,058 & 10,294 & 10,219 \\
\hline North & $20.4 \%$ & $18.3 \%$ & $*$ & 9,355 & 8,501 & * \\
\hline East & $17.1 \%$ & $16.4 \%$ & * & 11,931 & 10,892 & * \\
\hline Northwest & $10.0 \%$ & $10.0 \%$ & $10.0 \%$ & 10,156 & 8,920 & 8,597 \\
\hline Northcentral & $14.4 \%$ & $11.4 \%$ & $12.3 \%$ & 8,161 & 7,440 & 7,755 \\
\hline Uva & $14.5 \%$ & $6.8 \%$ & $4.7 \%$ & 8,842 & 6,685 & 6,471 \\
\hline Sabaragamuwa & $15.3 \%$ & $13.5 \%$ & $12.1 \%$ & 12,027 & 10,826 & 9,068 \\
\hline \multicolumn{7}{|c|}{ For women with tertiary education } \\
\hline Western & $0.7 \%$ & $0.8 \%$ & $0.0 \%$ & 36,898 & 34,678 & 41,185 \\
\hline Central & $9.5 \%$ & $11.9 \%$ & * & 26,791 & 25,201 & * \\
\hline Southern & $21.5 \%$ & $22.9 \%$ & $20.0 \%$ & 24,063 & 23,809 & 24,798 \\
\hline North & $6.9 \%$ & $7.9 \%$ & * & 27,323 & 27,034 & * \\
\hline East & $15.8 \%$ & $15.8 \%$ & * & 24,461 & 24,313 & * \\
\hline Northwest & $17.4 \%$ & $19.5 \%$ & $10.0 \%$ & 28,099 & 28,377 & 29,778 \\
\hline Northcentral & $0.0 \%$ & $0.0 \%$ & $0.0 \%$ & 23,575 & 25,538 & 25,600 \\
\hline Uva & $3.1 \%$ & $1.9 \%$ & * & 23,108 & 22,138 & * \\
\hline Sabaragamuwa & $6.3 \%$ & $7.5 \%$ & $10.0 \%$ & 19,977 & 21,187 & 24,318 \\
\hline
\end{tabular}

Source: Authors' computations using 2013 LFS (DCS) micro data

* Either no estate sector/no tertiary educated in the sample for the estate sector 
Table 7: Logistic regression coefficient and significance* estimates for different levels of education

\begin{tabular}{|c|c|c|c|c|c|c|}
\hline \multirow[t]{2}{*}{ Logistic regression variables } & \multicolumn{2}{|c|}{$\begin{array}{r}\text { Never schooled or only } \\
\text { primary }\end{array}$} & \multicolumn{2}{|c|}{ Only Lower secondary } & \multicolumn{2}{|c|}{ GCE O/L Failed } \\
\hline & $\mathrm{B}$ & P-value & B & P-value & $\mathrm{B}$ & P-value \\
\hline Is married & .723 & 0.000 & 1.099 & .000 & 1.408 & .000 \\
\hline Have children below 10 years & .464 & .000 & .327 & .000 & .458 & .000 \\
\hline Ethnicity & & .000 & & .000 & & .000 \\
\hline \multicolumn{7}{|l|}{ Reference category- Sinhala } \\
\hline Tamil & .159 & .275 & .200 & .199 & .220 & .163 \\
\hline Moor & 1.130 & .000 & 1.212 & .000 & 1.363 & .000 \\
\hline Other & .713 & .397 & 1.556 & .149 & .783 & .313 \\
\hline Household income quintile & & .001 & & .045 & & .000 \\
\hline \multicolumn{7}{|l|}{ Reference category- $1^{\text {st }}$ quintile } \\
\hline $2^{\text {nd }}$ quintile & -.386 & .002 & .084 & .524 & -.046 & .686 \\
\hline $3^{\text {rd }}$ quintile & -.433 & .001 & -.007 & .958 & -.017 & .882 \\
\hline $4^{\text {th }}$ quintile & -.517 & .000 & -.277 & .041 & -.425 & .000 \\
\hline $5^{\text {th }}$ quintile & -.515 & .002 & -.179 & .241 & -.499 & .000 \\
\hline Sector & & .000 & & .000 & & .000 \\
\hline \multicolumn{7}{|l|}{ Reference category- Urban } \\
\hline Rural & -.174 & .187 & -.169 & .142 & -.364 & .000 \\
\hline Estate & -1.507 & .000 & -1.531 & .000 & -.920 & .000 \\
\hline Province & & .000 & & .000 & & .000 \\
\hline \multicolumn{7}{|l|}{ Reference category- Western } \\
\hline Central & -.072 & .651 & -.384 & .012 & -.041 & .738 \\
\hline Southern & -.024 & .879 & -.329 & .026 & -.014 & .893 \\
\hline North & .935 & .000 & .547 & .009 & .456 & .031 \\
\hline East & .855 & .000 & .165 & .378 & .123 & .507 \\
\hline Northwest & -.017 & .929 & -.110 & .481 & -.307 & .019 \\
\hline Northcentral & .110 & .599 & .032 & .872 & -.330 & .012 \\
\hline Uva & -.405 & .030 & -.335 & .065 & -.557 & .000 \\
\hline Sabaragamuwa & -.004 & .982 & -.514 & .004 & -.230 & .095 \\
\hline Constant & -.210 & .247 & -.158 & .352 & -.206 & .150 \\
\hline Predictability & & $69.70 \%$ & & $70.9 \%$ & & $71.3 \%$ \\
\hline
\end{tabular}

*B - regression coefficients; $\mathrm{p}<0.01$ statistically significant at $99 \%$ level of confidence; $\mathrm{p}<0.05$ statistically significant at $95 \%$ level of confidence; $p<0.1$ statistically significant at $90 \%$ level of confidence. 
Table 8: Logistic regression coefficient and significance ${ }^{* *}$ estimates for different levels of education

\begin{tabular}{|c|c|c|c|c|c|c|}
\hline \multirow[t]{2}{*}{ Logistic regression variables } & \multicolumn{2}{|c|}{ GCE O/L passed } & \multicolumn{2}{|c|}{ GCE A/L passed } & \multirow[b]{2}{*}{ B } & \multirow{2}{*}{$\begin{array}{l}\text { Tertiary } \\
\text { P-value }\end{array}$} \\
\hline & $\mathrm{B}$ & P-value & $\mathrm{B}$ & P-value & & \\
\hline Is married & 1.345 & .000 & 1.409 & .000 & 1.183 & .006 \\
\hline Have children below 10 years & .692 & .000 & .660 & .000 & .400 & .204 \\
\hline Ethnicity & & .004 & & .000 & & .195 \\
\hline \multicolumn{7}{|l|}{ Reference category- Sinhala } \\
\hline Tamil & .121 & .528 & .091 & .645 & .464 & .502 \\
\hline Moor & .720 & .000 & .721 & .000 & .160 & .827 \\
\hline Other & .648 & .262 & 1.767 & .103 & 3.615 & .037 \\
\hline Household income quintile & & .000 & & .000 & & .000 \\
\hline \multicolumn{7}{|l|}{ Reference category- $1^{\text {st }}$ quintile } \\
\hline $2^{\text {nd }}$ quintile & -.007 & .969 & -.678 & .004 & -.398 & .661 \\
\hline $3^{\text {rd }}$ quintile & -.221 & .179 & -1.121 & .000 & -.384 & .630 \\
\hline $4^{\text {th }}$ quintile & -.651 & .000 & -1.534 & .000 & -2.030 & .013 \\
\hline $5^{\text {th }}$ quintile & -1.039 & .000 & -2.174 & .000 & -2.585 & .001 \\
\hline Sector & & .000 & & .002 & & .671 \\
\hline \multicolumn{7}{|l|}{ Reference category- Urban } \\
\hline Rural & -.479 & .000 & -.256 & .005 & -.254 & .392 \\
\hline Estate & -1.232 & .000 & -.779 & .010 & -.459 & .708 \\
\hline Province & & .000 & & .000 & & .051 \\
\hline \multicolumn{7}{|l|}{ Reference category- western } \\
\hline Central & -.468 & .002 & -.566 & .000 & -1.275 & .052 \\
\hline Southern & -.349 & .006 & -.507 & .000 & -1.571 & .008 \\
\hline North & -.010 & .969 & -.434 & .100 & -.524 & .507 \\
\hline East & -.071 & .721 & -.791 & .000 & -1.429 & .053 \\
\hline Northwest & -.317 & .056 & -.303 & .070 & -.984 & .073 \\
\hline Northcentral & -.410 & .025 & -.254 & .221 & .164 & .776 \\
\hline Uva & -.820 & .000 & -.825 & .000 & -1.400 & .185 \\
\hline Sabaragamuwa & -.652 & .000 & .145 & .438 & -.071 & .891 \\
\hline Constant & .185 & .318 & .434 & .046 & -1.022 & .230 \\
\hline Predictability & & $71 \%$ & & $69.6 \%$ & & $90.2 \%$ \\
\hline
\end{tabular}

${ }^{* *}$ B - regression coefficients; $p<0.01$ statistically significant at $99 \%$ level of confidence; $p<0.05$ statistically significant at $95 \%$ level of confidence; $p<0.1$ statistically significant at $90 \%$ level of confidence. 


\section{Information from the qualitative data}

Though the quantitative analysis shows the supply side and demand side variables affecting women's labor force participation, the quantitative analysis does not provide an explanation as to why, compared to the lower and higher educated, a large share of upper secondary leavers opt out of the labor force. The quantitative descriptive analysis showed that stay at home women are highest among the upper secondary dropouts but still no explanation has emerged from the quantitative data. A reason could be that, because they are more educated than primary or lower secondary dropouts their reservation wages is higher, discouraging them to work at lower wage rates, especially in the informal sector, where many of the primary and lower secondary dropouts find employment. The qualitative interviews with labor market experts focused on understanding why a large share of upper secondary dropouts chose to opt out of the labor force.

Information emerging from interviews with labor market experts revealed that upper secondary dropouts, though academically at a comparatively higher level of education, are unlikely to possess both hard skills and soft skills required to access jobs that meet their employment and wage expectations. The experts consulted by the researchers informed that technical and vocational education mainly targets upper secondary dropouts who cannot access tertiary education, but male enrolments for vocational education are higher than the female enrolments, showing a clear gender segregation in accessing vocational training. They ruled out any gender discrimination or segregation in the intakes to vocational training institutions but emphasized that gender-based exclusions are not institutionally imposed, and the information suggested that they are more or less self-imposed by the women. They noted that it was personality, physical, mental and social constraints that made females difficult to survive the training in some industries. Due to these physical, mental and social demands of such training and in the prospective jobs, females are reluctant to apply for certain types of skills development and vocational training programs which, however, are much sought after in the job market. Labor Market Bulletin (Tertiary and Vocational Education Commission, 2013) shows that female enrolments are likely to be higher in the fields of languages, textile and garment, personal and community development and office management, and male enrolments are higher in the fields of building and construction, automobile repair and maintenance metal and light engineering. This indicates self-imposed gender segregation of technical and vocational training. The least number of the female enrolments are in fields related to plastic and rubber, marine and nautical science and mechatronics technology, automobile repair, maintenance, building and construction. These self-imposed restrictions affect women accessing the skills demanded in the market. It was also revealed that in some fields (e.g. automobile industry training) which were in the past accessed mainly by men, participation of women is gradually increasing.

These discussions, however, suggested gender discrimination in the labor market. Though vocational training is not gender segregated, there is a gender bias imposed by employers for certain types of jobs. The qualitative information suggested that gender segregation of jobs was likely to be a more serious issue in the private sector and hence largely affecting female employment.

The third important point that emerged in the discussions is the very poor knowledge on possibilities of career diversification among those who have undergone vocational training. For example, it was noted that graduates from the automobile mechanics programme, despite their ability to work as specialists in automobile spare parts, which are compatible with their personal, mental and social capacities, do not attempt such carriers, possibly because they do not have the carrier guidance that would help them to build carriers within the trained industry, fitting to their personal, mental and social needs. Thus, the under-development in carrier guidance was noted as another factor affecting labor force participation of upper secondary dropouts.

The discussions revealed that absence of soft skills was another important factor which deterred access to jobs. Despite vocational training providing hard skills, training on soft skills also remains at an under-developed state.

\section{SUMMARY AND CONCLUSIONS}

The quantitative analysis shows that largest share of women who stay at home without participating in the labor force are those who dropped out of school at the upper secondary level of education. Further, the highest incidence of stay at home women is found among women with upper secondary education. In the poorest income quintile, though share of women who stayed at home was low, the incidence of stay at home women was very high. The lowest share and incidence of stay at home women were those with tertiary education. The low incidence of stay at home women among the tertiary educated indicates availability of opportunities for employment at their expected wage levels. On the other hand, high incidence of upper secondary school dropouts choosing to stay at home suggests that their reservation wages are likely to be unrealistically higher than that offered in 
the labor market and that they are unwilling to accept employment at low wages.

Across income quintiles, the share of stay at home women in the poorest income quintile is low, but the incidence of stay at home women turn out to be highest in the poorest quintile. The low share is due to the number of prime working age women in the poorest quintile being relatively low compared to the prime working age women in the other quintiles. A large share of men and women in the poorest income quintile are old aged, and are beyond the prime working age; therefore, in relation to the other quintiles, the share of prime working age women as well as stay at home women are low in the poorest income quintile. But relative to the size of the prime working age women population in the poorest quintile, incidence of stay at home women are high, indicating that many women in the lowest income decile are not in the labor force. Low education among the poor, lack of skills in accessing job markets, lack of job market information and social networks might be preventing women entering the labor market. Men in the poorest income quintile are in precarious employment which are physically strenuous and therefore, despite the need to survive only a low share of women opt to enter the precarious labor market.

In terms of factors that explain labor market nonparticipation, quantitative data suggests that with the exception of marital status and household income, the supply side factors and demand side factors affecting the labor force participation of all groups, except those with tertiary education were the same. Irrespective of education attainment, being married and the availability of household income were very significant factors explaining non-participation in the labor force. Labour force participation of the tertiary educated was not affected by maternal status, ethno-religious identity or labor market factors, indicating that where employability is high, the role of maternal status and ethno-religious identity play only a minor role. The qualitative data suggests that the reservation wages of women with upper secondary education are likely to be high, compared to that of the lower educated; however, the absence of soft and hard skills required to access jobs, meeting their reservation wage levels and absence of adequate employment guidance are likely to be important factors discouraging labor force participation of the relevant category of women. Except for the tertiary educated, a highly significant constant in the regressions suggests the play of additional factors affecting the labor force participation choice.

In particular, the high incidence of upper secondary school dropouts staying at home without joining the labor force, suggests additional factors not addressed in the quantitative analysis. The qualitative analysis undertaken to explore these additional factors reveals that, women with upper secondary education are unlikely to accept the same employment as those with lower education because they are relatively better educated, but the absence of soft and hard skills required to access jobs meeting their requirements discourage upper secondary dropouts' participation in the labor force. The qualitative data also suggest that, beyond the mismatch of skills, absence of soft and hard skills demanded by the market, the absence of employment guidance is likely to be a key reason for secondary school dropout women's nonparticipation in the labor force.

The findings indicate that, to encourage women to participate in the labor force, especially the upper secondary leavers, diversification of vocational training focusing on current and future demands in the job market, expansion for vocational training intakes, development of soft skills training facilities and development of career guidance are key areas requiring policy interventions.

\section{ACKNOWLEDGEMENTS}

The authors acknowledge the Department of Census and Statistics for providing micro data of Labor Force Survey- 2014 and also acknowledge the comments and suggestions from the anonymous referees, which helped improving this article.

\section{END NOTES}

1. Authors' calculations based on Department of Census \& Statistics (DCS) Labor Force Survey (LFS) reports for various years.

2. All women above $15+$ years of age.

3. Labor force consists of all individuals, $15+$ years of age who are working or seeking work. More detailed definition is given in the Annual Labor Force Survey Reports of the Department of Census \& Statistics.

4. Authors' calculations based on Department of Census \& Statistics Labor Force Survey reports for various years.

5. Women who are 15 years or more.

6. Authors' calculations based on Department of Census \& Statistics Labor Force Survey reports for various years.

7. Generated by the Department of Census and Statistics. 
8. International definition of prime working age (OECD Fact Book, 2011).

9. GCE O/L : Government Certificate of Education Ordinary Level examination.

10. GCE A/L : Government Certificate of Education Advanced Level Examination, passing which qualifies for university education.

11. Skills to access employment are obtained either through university education or from public or private sector Technical and Vocational Education and Training Institutions. University entrance depends on the level of achievement at GCE A/L and only about $10 \%$ of the students who passes the examination are selected for university education. About $40 \%$ of the intake to public Technical Vocational Education \& Training (TVET) institutions target dropouts with GCE O/L qualifications, followed by $20 \%$ without GCE O/L, and $15 \%$ with GCE A/L.

12. Incidence is defined as the share of prime working age stay at home women from among all prime working age women.

13. The school year/Grade passed.

14. Either never married or widowed or divorced or separated and not living with a husband.

15. Married and having a husband.

16. Children 10 years old or below.

\section{REFERENCES}

Asian Development Bank (2015) Innovative strategies in technical and vocational education and training for accelerated human resource development in South Asia- Sri Lanka, Philippines: Asian Development Bank [Online] Available from: https://www.adb.org/sites/default/files/publication/176571/ tvet-hrd-south-asia-sri-lanka.pdf [Accessed: 27 ${ }^{\text {th }}$ August 2017].

Blumberger, R. L. (1978) Stratification: Socio Economic \& Sexual Inequality, Iowa: William C. Brown.

Cahuc, P. and Zylberberg, A. (2004) Labor economics, Massachusetts, USA: MIT Press [Online] Available from: https://mitpress.mit.edu/books/labor-economics [Accessed: $27^{\text {th }}$ August 2017].

Chowdhury, A. (2013) Low Female Labour Force Participation in Sri Lanka: Contributory Factors, Challenges and Policy Implications, South Asia: Human Development Sector Discussion Paper Series; No. 68, Washington, DC: World Bank
[Online] Available from: https://openknowledge.worldbank. org/handle/10986/17871 [Accessed: 27 ${ }^{\text {th }}$ August 2017].

Cotter, D. A., De Fiore, J., Hermsen, J. M., Kowalewski, B. M. and Venneman, R. (1998) The demand for female labor, American Journal of Sociology, 103(6), pp: 16731712 [Online] Available from: https://www.jstor.org/ stable/10.1086/231404?seq=1\#page_scan_tab_contents [Accessed: 27 $7^{\text {th }}$ August 2017].

Department of Census and Statistics (HIES) (2009/10) Household Income and Expenditure Survey, Colombo: Department of Census and Statistics [Online] Available from: http://www.statistics.gov.lk/HIES/PreReportHIES2009Eng. pdf [Accessed: 24 ${ }^{\text {th }}$ September 2017].

Department of Census and Statistics (LFS) (2010-2014) Sri Lanka Labour Force Statistics Quarterly Bulletin, Colombo: Department of Census \& Statistics [Online] Available from: http://www.statistics.gov.lk/samplesurvey/LFS_Q1_Bulletin WEB_2014_final.pdf [Accessed: 27 ${ }^{\text {th }}$ August 2017].

Department of Census and Statistics (HIES) (2012/13) Household Income and Expenditure Survey, Colombo: Department of Census and Statistics [Online] Available from: http://www.statistics.gov.lk/HIES/HIES2012_13FinalReport. pdf [Accessed: 24 ${ }^{\text {th }}$ September 2017].

Gunatilaka, R. (2013) To work or not to work? Factors holding women back from market work in Sri Lanka, ILO Asia Pacific Working Paper Series [Online] Available from: http://www.oit. org/wcmsp5/groups/public/---asia/---ro-bangkok/---sro-new_ delhi/documents/publication/wcms_250111.pdf [Accessed: $27^{\text {th }}$ August 2017], New Delhi: ILO.

Huber, J. (1990) Macro-Micro links in gender stratification, American Sociological Review, 55, pp: 1-10 [Online] Available from: https://www.jstor.org/stable/2095699?seq=1\#page_ scan_tab_contents [Accessed: $27^{\text {th }}$ August 2017].

Kabeer, N. (2013) Women's economic empowerment and inclusive growth: labour markets and enterprise development, SIG Working Paper 2012/1 [Online] Available from: https:// www.idrc.ca/sites/default/files/sp/Documents\%20EN/NKWEE-Concept-Paper.pdf [Accessed: 27 ${ }^{\text {th }}$ August 2017].

Kotikula, A. and Sorotaroff, J. (2006) Gender Analysis of Labour in the Sri Lanka estate Sector [Online] Available from: http://paa2007.princeton.edu/papers/71572 [Accessed: 27 $7^{\text {th }}$ August 2017].

Macionis, J. J. (2010) Sociology, 13 ${ }^{\text {th }}$ Ed., London: Pearson.

Malhotra, A. and Degraff, D. (2000) Daughters and wives: Marital status, poverty and young women's employment in Sri Lanka, In Garcia, B. (Ed.) Women, Poverty and Demographic Change, London: Oxford University Press, pp: 145-174. 
Reskin, B. and Cassirer, N. (1996) Occupational segregation by gender, race and ethnicity, Sociological Focus, 29(3), pp: 231-243 [Online] Available from: https://www.tandfonline. com/doi/abs/10.1080/00380237.1996.10570642 [Accessed: $27^{\text {th }}$ August 2017].

Tertiary and Vocational Education Commission (TVEC) (2013) Labour Market Information Bulletin, Colombo: TVEC, Ministry of Youth Affairs and Skills Development.
Verick, S. (2014) Female labor force participation in developing countries, Bonn: IZA World of Labour [Online] Available from: https:/wol.iza.org/uploads/articles/87/pdfs/female-laborforce-participation-in-developing-countries.pdf [Accessed: $24^{\text {th }}$ September 2017].

World Bank (2015) World Bank data [Online] Available from: https://data.worldbank.org/indicator [Accessed: $24^{\text {th }}$ September 2017]. 